\title{
Effect of exposure of cotton dust on pulmonary function tests in female workers of spinning mill at Malegaon, Maharashtra
}

\author{
Jadhav A. $\mathbf{J}^{1}$, Mankar S. $\mathbf{R}^{2}$, Dange C. $\mathbf{D}^{3}$ \\ ${ }^{1}$ Mrs. Anita J. Jadhav, Medical Physiology, ${ }^{2}$ Dr. Shital R. Mankar, Assistant Professor, ${ }^{3}$ Dr. Chadrashekhar D. Dange, \\ Assistant Professor. All are affiliated with Department of Physiology, Shri. Bhausaheb Hire Government Medical \\ College, Dhule, Maharashtra, India.
}

Address for Correspondence: Dr. Shital Rameshrao Mankar, Assistant Professor, Department of Physiology, Shri Bhausaheb Hire Government Medical College, Dhule, Maharashtra, Email id: smankar500@gmail.com

\begin{abstract}
Background: Textile industry is the only industry to have employed women workers since long time. There are many respiratory problems develop in the women workers. Aims and Objective: The aim of this study was to assess the effects of exposure of cotton dust on the pulmonary function in the spinning mill female workers. Method: We enrolled 35 female (age $=18$ to 50 years) workers in study group who were regularly working in spinning mill and duration of exposure to cotton dust was noted. Inclusion criteria were clinically healthy, non-smokers, without chronic respiratory disease, systemic illness. Tobacco users were excluded. Control group consist 35 female (age $=18$ to 50 years) who were never in exposure of cotton wool. This study was conducted after obtaining ethical clearance and consent. MEDSPIRORCOMPUTERISED SPIROMETER was used to find out pulmonary function tests which were FVC, FEV1, FEV1/FVC and PEFR, which helped in evaluating pulmonary functions. Statistical Analysis: Unpaired students ' $\mathrm{t}$ ' test was applied to compare the PFT parameters in study group and control group. The data was expressed as mean + standard deviation. Results: Greater declines were seen in forced vital capacity, forced expiratory volume in first second. This reduction was significant in FEV1/FVC which is indicator of early obstructive pattern in the exposed group. As duration of exposure increases FVC reduces and showed restrictive pattern. Conclusion: According to our study, cotton textile workers developed respiratory problems which reflects as reduces pulmonary function.
\end{abstract}

Keywords: Cotton Dust, Cotton textile workers, Pulmonary function.

\section{Introduction}

The status of women is directly connected with their economic position, which in turn depends on opportunities for participation in economic activities. The economic status of women is now accepted as an indicator of a society's stage of development. There are many health problems to which the women workers in textile industry is exposed. The major health problems associated with cotton dust are respiratory problems [1].

Cotton dust is a colorless, odorless solid particles. Workers are exposed to cotton dust particles which are in the sizes from 0.1 to 150 microns. They are released in to atmosphere during processing, picking, crushing, grinding, abrading and loading. The particles more than

Manuscript received $2^{\text {nd }}$ June 2016

Reviewed: $12^{\text {th }}$ June 2016

Author Corrected: $24^{\text {th }}$ June 2016

Accepted for Publication $7^{\text {th }}$ July 2016
10 microns settle down from the air rapidly while smaller particles remain suspended indefinitely. The particles which are smaller than 5 microns are directly inhaled in to lungs and retained there. This fraction of dust is called respirable dust and is mainly responsible for pneumoconiosis. When the workers exposed to cotton dust for more than 10 years their lung function altered which is depending on size of the particle, duration exposure [2].

It may contain substances such as: non-cotton matter, bacteria, fungi, soil and pesticides which may have accumulated during the growing of the plant, harvesting of the crop and subsequent processing and storage periods. Breathing in cotton dust can cause serious, permanent lung damage. The following respiratory conditions are associated with exposure to cotton dust: 
difficulty in breathing, chest tightness, coughing and wheezing.

Many studies have been documented the effects of cotton dust on pulmonary function among workers employed in cotton-spinning mills. However, little data exist on the prevalence of this disorder in female workers.

To examine the respiratory problems of women workers in the spinning mill a study was undertaken. Medical expenses were a big burden for these women. The women do not give much importance to their health. They try to work even when they are sick and weak, just to supplement the family income. The health hazards of the women working in the textile industry are much higher compared to their counter parts in other sectors. It is therefore an urgent need to assess the pulmonary functions in spinning millworkers.

\section{Aims and Objectives}

The aim of this study was to assess the effects of exposure of cotton dust on the pulmonary functions of females working in spinning mill of Malegaon, during their working hours.

\section{Material and Methods}

Selection and Description of Participants:

The present study was undertaken in spinning mill workers in Malegaon, Maharashtra. A total of 35 female spinning mill workers in the age group of 18 to 50 years were included in the study.

Approval was taken from the institutional ethical committee.

\section{Technical Information:}

\section{Project Instruments:}

- Examination proforma for obtaining medical history and for recording clinical examination.

- Portable weighing machine was used to record the weight in $\mathrm{kg}$.

- Measuring tape was used to measure the standing height in centimeters

- MEDSPIROR-COMPUTERISED SPIROMETER respiratory analysis system was used to perform the pulmonary function tests (PFTs).

History and Clinical Examination: A thorough history was collected from all the participants including personal history such as name, age, sex, ethnicity, address, habit of smoking and medical history including history of any respiratory and cardiac diseases. All the subjects underwent an anthropometrical assessment including standing height and weight. The subjects for this study were included based on the following criteria.

Study Group: Enrolled 35 female (age=18 to 50 years) workers in study group who were regularly working in spinning mill.

Inclusion criteria will be clinically healthy, nontobacco users, without any chronic respiratory disease, systemic illness like diabetes, hypertension etc. Subjects were divided into three groups

Depending upon the duration of exposure to cotton dust as follows :-

Group I - Less than 5 years

Group II - Between 5-10 years

Group III - Between 10-15 years

Exclusion Criteria: Exclusion criteria were H/o chronic respiratory disease, $\mathrm{H} / \mathrm{o}$ cardiac disease etc. Examination finding suggestive of respiratory or cardiac disease, abnormal pulmonary function test, extremes of weight and height, continuous absence from the work.

Control Group consist 35 female (age $=18$ to 50 years) who were never in exposure of cotton wool. For pulmonary function test medspiror was used. The study was conducted on first working day after rest. Pulmonary function test was recorded at around morning session before the start of work. On the previous day, women were told to avoid any physical exertion and take proper rest and diet. The data of the subject as regards name, age, height, weight, sex, date of performing the test, atmospheric temperature was fed to the Spirometer. The tests were performed in sitting position. The subject was asked to take full inspiration which was followed by as much rapid and forceful expiration as possible in the mouthpiece of Medspiror. Three consecutive readings were taken and the best reading amongst the three was selected. We have followed the guidelines of American Thoracic Society. [3] PFT of study group and control group was obtained. The pulmonary function tests included were forced vital capacity (FVC) [L], forced expiratory volume $1 \mathrm{~s}$ (FEV1) [L], FEV1/FVC, peak expiratory flow (PEFR) [L/S], carried out by computerized spirometer. All these parameters helped in evaluating pulmonary functions among workers. 
The procedure for doing test parameters for FVC, the subjects were asked to execute fast forceful expiration as much as possible at the end of deep inspiration. This test was repeated 2 or 3 times, and the best values were obtained.

Statistics: The data collected was entered in the MS Excel spreadsheet. Descriptive table was generated, and appropriate statistical analysis was performed using SPSS (version 10). Student's t-test was applied to compare the PFT parameters between study and control group. A significance level of "P" $<0.05$ was considered for the student's t-tests (unpaired t test). The data were expressed as mean + standard deviation. By applying ANOVA test to the observed values of group I, II, III.

\section{Results}

Table- I: Anthropometric profile (female $n=35$ ).

\begin{tabular}{|c|c|c|}
\hline Basal Values & $\begin{array}{c}\text { Female }(\mathbf{n}=35) \\
(\text { control group) mean+SD }\end{array}$ & $\begin{array}{c}\text { female }(\mathbf{n}=35) \\
\text { (study group) mean+SD }\end{array}$ \\
\hline Age (years) & $37.0 \pm 8.3$ & $38.03+9.07$ \\
\hline Height $(\mathrm{cm})$ & $158.62+3.93$ & $153.42+5.8$ \\
\hline Weight $(\mathrm{kg})$. & $50.20+11.87$ & $49.84+7.30$ \\
\hline
\end{tabular}

According to Table I control and study groups are comparable.

Table- II: lung functions in female workers STUDY GROUP (n=female 35)

\begin{tabular}{|c|c|c|c|c|c|c|}
\hline \multirow[t]{2}{*}{ Parameters } & \multicolumn{2}{|c|}{$\begin{array}{c}\text { Group I } \\
(n=9)\end{array}$} & \multicolumn{2}{|c|}{$\begin{array}{c}\text { GroupII } \\
(\mathrm{n}=11)\end{array}$} & \multicolumn{2}{|c|}{$\begin{array}{c}\text { GroupIII } \\
(n=15)\end{array}$} \\
\hline & $\mathbf{P}$ & $\begin{array}{c}\text { O } \\
\text { Mean +SD }\end{array}$ & $\mathbf{P}$ & $\begin{array}{c}\mathrm{O} \\
\text { mean+SD }\end{array}$ & $\mathbf{P}$ & $\begin{array}{c}\mathrm{O} \\
\text { mean+SD }\end{array}$ \\
\hline $\mathrm{FVC}(\mathrm{L})$ & $2.24+0.20$ & $1.71+0.37$ & $2.23+0.14$ & $1.60+0.20$ & $1.92+0.17$ & $1.33+0.20$ \\
\hline FEV1 (L) & $1.78+0.17$ & $1.44+0.33$ & $1.76+0.16$ & $1.63+0.21$ & $1.46+0.12$ & $1.2+0.26$ \\
\hline FEV1/FVC & $87.55+7.35$ & $75.11+13.11$ & $90.36+8.8$ & $84.27+9.6$ & $88.46+0.69$ & $80.13+6.06$ \\
\hline PEFR (L/S) & $5.9+0.6$ & $3.4+0.82$ & $5.81+0.39$ & $3.03+1.10$ & $5.52+0.79$ & $2.65+0.87$ \\
\hline
\end{tabular}

$\mathrm{P}=$ Predicted Value., $\mathrm{O}=$ Observed Value

According to Table no. II there was progressive decrease in PFT values as duration of exposer to cotton dust increases. It also showed that in all groups decreased observed values of PFT parameters compare to predicted value.

Table-III: Comparison of lung functions in female workers study and control group (n=female 35).

\begin{tabular}{|c|c|c|c|c|}
\hline Parameters & $\begin{array}{c}\text { PFT values control } \\
\text { group mean }+ \text { SD }\end{array}$ & $\begin{array}{c}\text { PFTvalues study } \\
\text { group } \\
\text { Mean }+ \text { SD }\end{array}$ & P Value & Significance \\
\hline FVC (L) & $2.16+0.21$ & $1.58+0.2$ & $<0.001$ & Significant \\
\hline FEV1 (L) & $2.40+0.2$ & $1.42+0.28$ & $<0.001$ & Significant \\
\hline FEV1/FVC & $88.03+9.4$ & $74.14+10.95$ & $<0.05$ & Significant \\
\hline PEFR (L/S) & $5.6+0.74$ & $2.72+0.97$ & $<0.001$ & \\
\hline
\end{tabular}

Values in mean+S. D. *P Value $<0.05, * * \mathrm{P}<0.001, * * * \mathrm{P}<0.0001, \mathrm{~ns}=$ not specified

Table-III depicts that cotton mill workers showed significant decreased in FVC, FEV1, FEV1/FVC, PEFR levels when compared to controls. 


\section{Discussion}

Women in developing countries are often in poor health and are overburdened with work, they are tired, most are anemic and many suffer from malnutrition and parasitism and chronic ill health especially, during pregnancy and childbirth. Women's special needs have often been ignored by health planners and women have thus had to bear a disproportionate share of unmet health needs. Textile workers exposed to the textile related cotton dust and some other type of illness throughout the manufacturing process are of great health hazards.

The anthropometric parameter like age, height, weight of study group and control showed no significant difference thus making group comparable.

The health hazards of the women working in the textile industry are much higher compared to their counter parts in other sectors. It is therefore an urgent need on the part of the policy makers to take effective steps to better the condition of women in textile industry [1].

The present study showed that the workers in spinning industry are exposed to high levels of cotton dust. Respiratory tract diseases are very common, among the spinning mill workers as a result of inhalation of cotton fibers and dust in work place. The most common respiratory health problems were cough, chest pain and dyspnea according to history.

Inhalation of cotton dust causes release of histamine from mast cells. Histamine acts on the smooth muscles resulting broncho constriction. Air way mucus glands secrete more amount of mucus in the presence of histamine. Histamine directly stimulates vagal nerves causing smooth muscle contraction. Contraction of smooth muscles of air ways reduces the air entry in to lungs [4].

Organic dust exposure in the textile industry leads to obstructive lung disease that has features of both asthma and COPD. Cessation of workplace exposure may lead to improved lung function. An inversion of the pulmonary macrophage: dendritic cell ratio may be a mechanistic explanation for persistent inflammation and obstructive lung disease seen in endotoxin-related textile exposures.

In our study, the exposed workers had more persistent respiratory symptoms and a lower FEV1 compared to the comparison group of unexposed workers (table-III). Our results are comparable with earlier reports that have established a relationship between exposure to cotton dust and impaired pulmonary function which is in agreement with the study of Saadat Ali Khan Aizasaadia [5].

FEV1 showed significantly decreased values in the cotton workers when compared with controls is in accordance with the studies of Wang XR [6], Glindmeyer HW [7] Ramaswamy, P [8], Bakirci N [9].

Some researchers found that the mean FEV1 and FVC in those exposed to cotton dust were significantly lower than those in a comparison group [10, 11, 12]. Chattopadhyay, et al, reported typical symptoms of byssinosis along with acute cross-shift as well as chronic changes in FEV1 among workers exposed to cotton. [13]. Xiaorong, et al, in their study indicated that workers exposed to cotton dust had larger and more frequent drops in FEV1, as well as excessive chronic declines in FEV1 compared to silk workers. They also showed a relationship between cross-shift decline and chronic declines in FEV1 [14].

In the present study cotton mill workers showed significant decreased in FVC, FEV1, FEV1/FVC, PEFR levels when compared to controls (Table-III) and there was progressive decrease in PFT values as duration of exposer increases. (Table-II).

FEV1/FVC reduced indicate obstructive changes in small duration of cotton dust exposer but as duration increases restrictive changes also found which to reduce FVC (Table-II). Similar type of result was obtained by V. S. Dhanashree Naidu et al [15].

The result of this study shows the decline in PEFR that may be due to the effects exposure with cotton dust. Present result showed relation between respiratory symptoms and decline in PEFR. Similar results were obtained by Tiwari et al [16], and Boezen et al [17] showed decline in PEFR and increased symptoms as age and duration of exposure was increases.

Continuous expouser to dust causes progressive impairment of lung function and adversly affect FVC, FEV1, PEFR causes obstructive and restrictive patter $n$ of lung function associated with duration of exposer. [15] It was observed that FEV1 and PEFR were 
significantly decreased $(p<0.001)$ level of significance. FEV1 was significantly reduced, which is indicative of obstructive pulmonary disease. This shows that exposure to saw dust causes obstructive pulmonary impairment.

PEFR shows significant decrease in groups. This suggests that cotton dust has an effect on PEFR.

\section{Conclusion}

Cotton dust causes obstructive changes as is evidenced by decrease in FEV1, FVC/FEV1, PEFR which are more prominently seen in group I and group II. It can cause bronchoconstriction in first few years of exposure. It also decrease FVC in female those have exposure of more duration of years. That mean it causes obstructive as well as restrictive changes in lung depends upon duration of exposure.

Scope of study: 1) Periodic medical examination should be performed to workers in the factory not only sample from them, the physician must be present daily in out patient factory clinic to provide medical services. 2) Health authorities should provide protective measures to workers such as ear plugs, disposable mask, worker clothes, fire protection and observation for using it. 3) Periodic inspection of working environment by industrial hygienist through regular measurement of noise level, illumination, humidity, ventilation and cotton dust concentration. 4) Training and health education programs should be provided to all workers from the start of work and regularly carried out to assist the worker adjustment to the working environment. 5) Emphasizing the correct use of personal protective measures.

Funding: Nil, Conflict of interest: None initiated, Permission from IRB: Yes

\section{References}

1. Sherly Thomas; A Study on the Health Problems of Women Working in a Textile Unit in Coimbatore International Journal of Science and Technology Volume 1 No.5, November 2011.

2. Siziya S, Munalula B, Respiratory conditions among workers in a cotton spinning mill in Zambia, ATDF Journal Volume 2, Issue 3; 2005.

3. Standardization of Spirometry, 1994 Update. American Thoracic Society. Am J Respir Crit Care Med. 1995 Sep; 152(3):1107-36.
4. PRABHAKARA RAO. K, SRINIVASARAO. CH, SUMANGALI, A STUDY OF PULMONARY FUNCTIN TESTS IN COTTON MILL WORKERS OF GUNTUR DISTRICT Bulletin of Pharmaceutical and Medical Sciences (BOPAMS) A Peer Reviewed International Journal Vol. 1. Issue.3.; 2013.

5. Saadat Ali Khan Aizasaadia. pulmonary function studies in Pakistani cotton ginners. Pak J Physiol 2006; 2(1).

6. Wang XR, Zhang HX, Sun BX, Dai HL, Hang JQ, Eisen EA, Wegman DH, Olenchock SA, Christiani DC. A 20-year follow-up study on chronic respiratory effects of exposure to cotton dust. Eur Respir J. 2005 Nov; 26(5):881-6.

7. Glindmeyer HW, Lefante JJ, Jones RN, Rando RJ, Abdel Kader HM, Weill H. Exposure-related declines in the lung function of cotton textile workers. Relationship to current workplace standards. Am Rev Respir Dis. 1991 Sep;144(3 Pt 1):675-83.

8. Ramaswamy, P; Sambandam, S; Ramalingam, A; Arnold, J; Balakrishnan, K F; Thanasekaraan, V. Pulmonary Functions of Workers in Textile Units of Tamilnadu, India: Isee-386. Epidemiology 2003 sep 14(5) supplement s76.

9. Bakirci N, Kalaca S, Francis H, Fletcher AM, Pickering CA, Tumerdem N, Cali S, Oldham L, Niven R. Natural history and risk factors of early respiratory responses to exposure to cotton dust in newly exposed workers. J Occup Environ Med.2007Aug;49(8):853-61.

10. Nagoda M, JU Okpapi, M Babashani. Assessment of respiratory symptoms and lung function among textile workersat Kano Textile Mills, Kano, Nigeria? Nigerian Journal of Clinical Practice 2012;15.

11. Jiang CQ, Lam TH, Kong C, Cui CA, Huang HK, Chen DC, He JM, Xian PZ, Chen YH. Byssinosis in Guangzhou, China. Occup Environ Med. 1995 Apr; 52(4):268-72.

12. Fishwick D, Fletcher AM, Pickering CA, McL Niven R, Faragher EB. Lung function in Lancashire cotton and man made fibre spinning mill operatives. Occup Environ Med. 1996 Jan; 53(1):46-50.

13. Chattopadhyay BP, Saiyed HN, Mukherjee AK. Byssinosis among jute mill workers. Ind Health. 2003 
Jul;41(3):265-72.

14. Wang X, Zhang HX, Sun BX, Dai HL, Hang JQ, Eisen E, Su L, Christiani DC. Cross- shift airway responses and long-term decline in FEV1 in cotton textile workers. Am J Respir Crit Care Med. 2008 Feb 1; 177(3):316-20. Epub 2007 Nov 1.

15. V. S. Dhanashree Naidu, V. S. Sai Sankalp Naidu et al 2014. Effect of cotton dust on pulmonary function among cotton textile workers MRIMS Journal of health science, volume 2 , issue 2 , july-december (72-77).

16. Tiwari RR, Zodpey SP, Deshpande SG, Vasudeo ND. Peak expiratory flow rate in handloom weavers. Indian J Physiol Pharmacol. 1998 Apr; 42(2):266-70.

17. Boezen HM, Schouten JP, Postma DS, Rijcken B. Relation between respiratory symptoms, pulmonary function and peak flow variability in adults. Thorax. $1995 \mathrm{Feb} ; 50(2): 121-6$.

\section{How to cite this article?}

Jadhav A. J, Mankar S. R, Dange C. D. Effect of exposure of cotton dust on pulmonary function tests in female workers of spinning mill at Malegaon, Maharashtra. Int J Med Res Rev 2016;4 (7):1233-1238.doi:10.17511/ijmrr.2016.i07.27. 